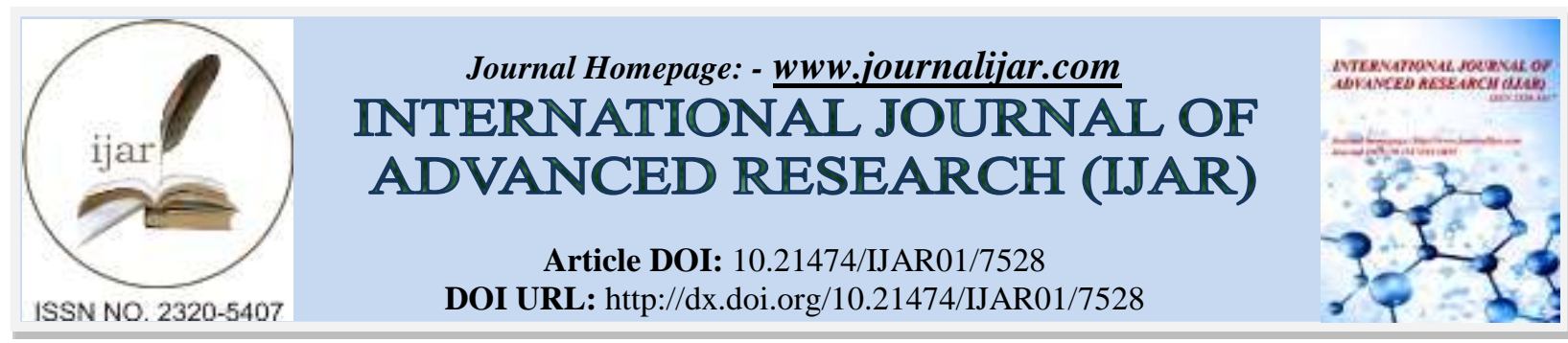

RESEARCH ARTICLE

\title{
TAXONOMY AND ECOLOGY OF TWO SYMPATRIC SPECIES OF LITSEA (L. BOURDILLONII GAMBLE AND L. FLORIBUNDA (BLUME) GAMBLE), LAURACEAE ENDEMIC TO WESTERN GHATS.
}

Fasila P. K ${ }^{1}$, Pradeep A. K. ${ }^{2}$, Amitha Bachan K. $H^{3}$, Girija T. $\mathbf{P}^{3}$ and Fouziya T. A ${ }^{4}$.

1. PhD Fellow, Research \& PG Department of Botany, MES Asmabi College, P. Vemballur, Thrissur Dt. Kerala 680671, India.

2. Assi. Prof., and Research Guide, Department of Botany, University of Calicut.

3. Assi. Prof. and Research Guide, Research \& PG Department of Botany, MES Asmabi College, P. Vemballur, Thrissur Dt. Kerala -680671, India.

4. Fellow, Western Ghats Hornbill Foundation, Aryanak Mathilakam, Thrissur Dt. Kerala -680671, India.

\section{Manuscript Info}

Manuscript History

Received: 10 June 2018

Final Accepted: 12 July 2018

Published: August 2018

\begin{abstract}
The members of Lauraceae, important components of the tropical forests has been considered as taxonomically difficult because of their similarity among closely related taxa, variations within taxa and smaller inconspicuous flowers. Two sympatric species of the genera Litsea, Litsea floribunda (Blume) Gamble, endemic to the Western Ghats and Litsea bourdillonii Gamble, endemic to the Southern Western Ghats were studied for their morphology, taxonomy, distribution and ecological niche. The species showed high similarity in the morphological features except few features of the inflorescence, fruiting pedicels and veins. Both the species share similar niche in the 700-1200m MSL wetevergreen forests in the Western Ghats.
\end{abstract}

Copy Right, IJAR, 2018,. All rights reserved.

\section{Introduction:-}

Laurales are important components of tropical evergreen and sub-tropical montane forests. Most of them are aromatic evergreen trees or shrubs except the genus Cassytha, which is a parasitic vine. The family comprises 2850 known species in 45 genera worldwide (Christenhusz \& Byng, 2016) mostly distributed in Southeast Asia and South America. Whitmore (1973) described the tropical rainforests of the far-east as the world of Laurales and Myrtales.

Although the taxonomy of the Lauraceae is still not settled, some of the recent estimate suggests 45 genera and 2850 species (Christenhusz \& Byng, 2016) but conservative estimates suggest possibility for 52 genera worldwide with 2550 species (Mabberley, 2008; Bhuinya et al. 2010). Compared to other plant families, the taxonomy of Lauraceae still is poorly understood. This is partly due to its great diversity, morphologic similarity between taxa and variations within the taxa leading to difficulty of identifying the species and also due to lack of adequate studies. The small and inconspicuous flowers also made them inaccessible for a nonspecialist.

\section{The Genus Litsea Lam:-}

Litsea Lam. is an important genera of the family Lauraceae with nearly 300 species (Mabberley, 2008; Bhuinya $e t$ al., 2010). They are mostly trees species, rarely shrubs. The main distribution area is located in the tropics and subtropics of Asia, some species are found in Australia and throughout the Americas. There are 45 species occur in 
India of which 18 species are endemic to different ecoregions (Bhuinya et al., 2010; Singh, 2011; IUCN 2018). Out of the 18 species of Litsea endemic to India 14 are endemic to Western Ghats and other 4 are endemic to North-East India.

There are 22 species distributed in Kerala of which 14 are Western Ghats Endemics, 4 are threatened species (IUCN, 2018). This study aims to provide a detailed account of morphology and taxonomy, distribution and ecological niche of the two sympatric species of litsea i.e. Litsea floribunda (Blume) Gamble endemic to the Western Ghats and Litsea bourdillonii Gamble endemic to the Southern Western Ghats. Both the species are small trees, morphologically very similar and distributed in the Evergreen and Wet Evergreen forests almost occupies a similar niche and are seen together.

\section{Methodology:-}

The specimens were collected (vegetative stages, multiples samples of flowering, young and mature fruiting stages and seeds) during field visits in important forest areas of Kerala ranging from Ponmudi-Agasthyamala region of Thiruvananthapuram District in the south upto the Silent Valley National Park in North. Detailed ecological studies were conducted in the evergreen forest areas of Vazhachal Forest Division and Parambikulam Tiger Reserve. The Sholayar - Malakkappara region was selected for detailed study because of the sympatric occurrence of these two species in the region. The identity of the specimens were confirmed by using important floristic works Flora of British India, (Hooker, 1886), Flora of presidency of Madras (Gamble, 1925) and regional floras (Manilal, 1988 ; Sasidharan \& Sivarajan, 1996; Mohanana \& Sivadasan, 2002; Anil Kumar et al., 2005). The herbariums were prepared following Van Balgooy (1987). Author citation and nomenclature was done by following Authors of Plant Names by Brummitt and Powel (1992) and The Plant Book (Mabberley, 2008).

Simple phytosociological methods were used to understand the community composition of the associated vegetation of each species and also the niche occupancy. Transects of $250 \mathrm{~m}$ long were laid at 12 random grids in the Sholayar area of the Vazhachal forest Division. All the important trees were identified and counted for their numbers with a width of three meters along the transect. GPS readings were taken at the beginning, end and regular intervals in each transects. The actual distance travelled was calculated plotting the GPS reading on Map Info GIS software.

The specific position of the selected species in the vegetation, their associated species and their population characteristics were estimated. Relative Density (RD) and Relative Frequency (RF) were calculated to elucidate Importance Value Index (IVI), an index to understand the importance of a particular species in a community. The species were then sorted to various height class such as Large, Medium, Medium and Small. The species with highest IVI values in each height class were identified as dominant associated species and hence the community composition and the niche of the two Litsea species under study were revealed.

GPS reading were taken from the study area for the two species of Litsea and collection locations were identified from herbarium specimens of each species during examination of specimens collected by various authors. The maps were created by plotting collection location of the two species across Google Map Interface. Each species were plotted with as specific colour tag.

\section{Result and discussion:- \\ Morphology, Taxonomy and Systematic Treatment \\ Litsea Lamarck \\ Encycl. 3:574. 1972, nom. cons.}

Litsea is an evergreen, rarely deciduous trees or shrubs. Leaves alternate or sometimes opposite, penninerved. Flowers dioecious, in umbellules of several together, usually 4-6 but in some cases up to 15, supported by 4-6 or more concave involucral bracts; the umbellules sessile or pedicelled in axillary or lateral clusters or in recemes, rarely solitary. Perianth tube in male flowers 0 or very small, in female flowers funnel-shaped; lobes normally 6 , sometimes more, sometimes 0 or very early caduceus, equal or unequal. Stamens in male flowers normally 9 or 12 in four rows, those of rows 1 and 2 usually eglandular, those of row 3 and row 4 when present with 2- glandular filaments; all stamens with 4 cells, the cells intorse or the lower pair lateral; ovary 0 or rudimentary. Staminoides in female flowers as the stamens of the male flowers but those of the outer rows clavate or linear, those of the inner rows subulate and 2-glandular; ovary enclosed in the perianth- tube or free; style thick, often curved; stigma dilated, 
irregularly lobed. Fruit a globose ovoid ellipsoid or oblong berry, seated on the enlarged perianth - tube with the more or less thickened pedicel; pericarp usually succulent. Seed with thin testa and fleshy cotyledons.

\section{Comparison of the two species}

Both the species the L. bourdillonii and L. floribunda have close morphological characters such as small evergreen trees, pubescent branchlets and leaves beneath, broad, obovate leaves and prominent secondary veins obliquely looping near margins. L. floribunda can be distinguished from L. bourdillonii with its long raceme, ovoid and silky pubescent fruits, broadly elliptic or oblong leaves with prominent reticulation. In L. bourdillonii inflorescence is sessile, fruits oblong and glabrous and the leaves are abruptly acute at apex.

\section{Key to the species}

1a. Umbellules in sessile or sub-sessile axillary or lateral clusters; Leaves obovate or obvate oblong, obtuse and abruptly acute at apex, cuneate at base, minutely fulvous - pubescent beneath; up to 9 in. long, 4 in. broad, main nerves 12-18 pairs, closer towards the base, berry oblong, $0.5 \mathrm{in}$. long, on a cup shaped 2-4 cleft glaborous, usually sessile perianth-tube, branchlets brownish black tomentose .................................. bourdillonii 3b. Umbellules in long racemes, Leaves ellpitic or obovate oblong, acute or acuminate, densely fulvous - tomentose beneath, upto 10 in. long, 4 in. broad, main nerves 10-15 pairs, prominent as are the transverse nervules; berry oblong, 0.5- .075 in. long, seated on the turbinate perianth tube with thick pedicel, young shoots densely reddishbrown tomentose, L. floribunda

1. Litsea bourdillonii Gamble, Bull. Misc. Inform. Kew 1925: 131. 1925 \& Gamble, Fl. Pres. Madras 1237. 1925; Mohanan, Fl. Quilon Dist. 347. 1984; C.J. Saldanha \& B.R. Ramesh in Saldanha, Fl. Karnataka 1: 66. 1984; V. Chandras. In A.N. Henry et al., Fl. Tamil Nadu 2: 209. 1987; M. Mohanan \& Henry, Fl. Thiruvanthapuram 394. 1994; Sasidh. \& Sivar., Fl. Pl. Thrissur For. 382. 1996; Sasidh., Fl. Shenduruny WLS 271. 1997; Sasidh., Fl. Periyar Tiger Reserve 349. 1998; Sasidh., Fl. Parambikulam WLS 269. 2002; Anil Kumar et al., Fl. Pathanamthitta 425. 2005. Ratheesh Narayanan, Fl. Stud. Wayanad Dist.700.2009. Bhuinya et al., Bangladesh J. Plant Taxon. 17(2): 183-191. 2010.

Small to medium sized trees upto 8-12 m high; branchlets are brownish to black coloured, tomentose, bark smooth, young shoots are reddish coloured. Leaves dark green, obovate to obovate-oblong, cuneate at base, acute at apex, reticulate venation, entire, simple, estipulate, alternate, 10-12 pair nerves under the leaf lamina it is exposed and at upper surface it is impressed, pinnate, pubescence on lower surface of leaf; petiole 10-15 mm long, stout, dark brown tomentose, Flower unisexual, sessile - subsessile, in axillary or lateral clusters of 2-5, flowers 4-6 in umbellule, peduncle thick, brown, flowers yellow to pale greenish bract two lobed, brown, $5 \mathrm{~mm}$ long, concave, densely white- tomentose; stamens 9-12, ovary half inferior, ovoid, style thick, stigma dialated. Fruit a berry, oblong, 12-14 mm long, seated on cupule like perianth tube, sessile closely attached to stem. Seeds obovate, $10-12$ mm long, brown, smooth, with thin testa.

Flowering and fruiting :December- may

Habitat \& Distribution :Endemic to Western Ghats, Kerala, Tamil Nadu. In Kerala, it is distributed in Thiruvananthapuram, Kollam, Pathanamthitta, Idukki, Thrissur, Palakkad and Wayanad districts.

Ecology and association: Distributed in evergreen and wet evergreen rainforest areas of the Western Ghats with an altitude ranges from 700-1200m. This species occurs in Cullenia- Palqium-Mesua dominated vegetation type.

Specimen examined: India, Kerala. Thiruvananthapuram Dist.: Bonacaud, Kovtheri, \pm 850 qm, 25 August 1975, J. Joseph 46519 (MH!); Ponmudi, 29 July 1978, M. Mohanan 569801 (MH!); ibid., 土1000 m, 07 March 1980 , M. Mohanan 66097 (MH!); Bonacaud, Kurisumala, \pm 750 m, 07 March 1979, M. Mohanan 5947 (MH!); Agasthyamala, 22 October 2003, P.S. Udayan et al. 1983 (CMPR!); Athirumala, 15 March 2008, P.S. Udayan et al. 4807 (CMPR!); Pandipath, 14 February 2009, P.S. Udayan et al. 5658 (CMPR!); Kollam Dist. Shenduruney, Kallar, 30 October 1992, N. Sasidharan 10042 (KFRI!); Pathanamthitta Dist.: Sabarimala, \pm 100 m, 18 March 1973, B.D. Sharma 43924 (MH!); Moozhiyar, \pm 350 m, 10 January 1988, N. Anilkumar 304 (MH!); Idukki Dist.: Devikolam, \pm 2000 m, 23 March 1980, K. Ramamurthy 60315 (MH!); Kulamavu, Meenmutty, \pm 700 m, 24 January 1983, A.G. Pandurangan 7613 (MH!); Meenmutty, \pm 700 m, 20 February 1983, C.N. Mohanan 76271 (MH!); Vellimala, 11 December 1994, Jomy Augustine 14337 (KFRI!); Pambadum shola, \pm 1800 m, 22 January 2009 , P.S. Udayan \& A.J. Robi 5465 (CMPR!); PTR Thannikudi, Ummikuppankudi, 17 March 2009, P.S. Udayan \& A.J. Robi 
5766 (CMPR!); Thannikkudi, 18 March 2009, P.S. Udayan \& A.J. Robi 5576 (CMPR!); Ernakulam Dist.: Pindimedu dam, 10 September 1985, K.K.N. Nair 3501 (KFRI!); Thrissur Dist.: Sholayar, \pm 700 m, 21 April 1981, N.G. Nair 1752 (KFRI!); ibid., \pm 725 m, 12 December 1988, N. Sasidharan 5243 (KFRI!); ibid., 22 March 1989, N. Sasidharan 5368 (KFRI!). Between Manali \& Meenkuthi, 11 February 1987, K.K.N. Nair 3280 (KFRI!), Pathadipalam-Sholayar 29 Jan 2015, P.K. Fasila 137406 (MESAH!) ; Palakkad dist.: Karappara dam, \pm 950 m, 27 December 1980, M.C. Nair 69840 (MH!); Parambikulam, Karimala, 14 February 2008, P.S. Udayan et al. 5200 (CMPR!); Nelliyampathy, Pulayanpaara, 05 June 2010, P.S. Udayan \& A.J. Robi 6892 (CMPR!); Wayanad Dist., Thirunelly, R. T. Balakrishnan, 40308 (900m).

2. Litsea floribunda (Blume) Gamble, Fl. Pres. Madras 1238. 1925; C.N Mohanan, Fl. Quilon Dist. 347. 1984; Manilal, Fl. Silent Valley 236. 1988; Ramach. \& V.J. Nair, Fl. Cannanore Dist. 395. 1988; Vajr., Fl. Palghat Dist. 405. 1990; M. Mohanan \& Henry, Fl. Thiruvanthapuram 394. 1994; Subram., Fl. Thenmala Div. 314. 1995; Sasidh. \& Sivar., Fl. Pl. Thrissur For. 382. 1996; Sivar. \& Mathew, Fl. Nilambur 587. 1997; Mohanan \& Sivad., Fl. Agasthyamala 569. 2002; Anil Kumar et al., Fl. Pathanamthitta 425. 2005; Amitha Bachan, Riparian Fl. of Chalakkudy River Basin 546. 2010. Bhuinya et al., Bangladesh J. Plant Taxon. 17(2): 183-191. 2010. Cylicodaphne floribunda Blume, Mus. Bot. Lugd.-Bat. 1: 387. 1851.Litsea wightiana Hook. f., Fl. Brit. India 5: 177.1886.

Medium to large sized trees to $15 \mathrm{~m}$ high, dioecious, 8-10 mm thick, light brown, Stem terete, young shoots reddish, with leaves clustered towards apex; petiole $2-3 \mathrm{~cm}$ long, Leaves elliptic, rounded at base, acuminate at apex, simple, entire, alternate, penninerved 10-15 pair lateral forming submarginal loop, hairy, young leaves pale brownish or reddish in color, lower surface densely brown tomentose, glabrous above. Inflorescence, racemose, peduncle thick, brown coloured. Flower, Male umbellules in axillary racemes; bracts densely tomentose; flowers 6-8 in each umbel, pale yellow, perianth silky; Stamens 12 in four rows, filament hairy; Female umbellules panicled, axillary and terminal. Fruit a berry, ovoid, $12 \mathrm{~mm}$ long, enclosed in a brown coloured cupule like perianth tube attached to pedicel, pale green at young and become reddish brown when mature. Seed oblong, brown colured with thin testa, $0.9 \mathrm{~mm}$ long.

Flowering and fruiting : Feb- April, November - May

Habitat \& Distribution :Endemic to Western Ghats, Maharashtra, Karnataka, Kerala, Tamil Nadu . In Kerala, it is distributed in Thiruvananthapuram, Pathanamthitta, Idukki, Thrissur, Palakkad, Malppuram, Kozhikode and Wayanad districts.

Ecology and association: Distributed in evergreen and wet evergreen rainforest areas of the Western Ghats with an altitude ranges from 700-1200m. This species occurs in Cullenia-Palqium-Mesua dominated vegetation type.

Specimen examined: $\quad$ India, Kerala. Thiruvananthapuram Dist.: Agasthyamala, \pm 1700 m, 14 October 1988 , N. Mohanan 4408 (TBGT!); Pongalapara, \pm 1400 m, 07 February 1988, N. Mohanan 9525 (TBGT!); Ponmudi, \pm 900 m, 17 January 1989, N. Sasidharan 5280 (KFRI!); Idukki Dist.: Kattapana, \pm 900 m, 13 November 1981, C.N. Mohanan 72490 (MH!); Moolamattam, \pm 700 m, 18 February 1982, C.N. Mohanan 73343 (MH!); Puliyanmala, \pm 1200 m, 14 December 1982, C.N. Mohanan 76139 (MH!); Chenthamara \pm 1000 m, 12 January 1994 Jomy Augustine 13453 (CALI!). Thrissur Dist.: Sholayar, \pm 700 m, 21 April 1981, N.G. Nair 1761 (KFRI!); Sholayar \pm 700 m, 13 March 2006, K.H. Amitha Bachan 99179; ibid., 20 April 2010, P.S. Udayan et al. 6725 (CMPR!); ibid., 20 April 2010, P.S. Udayan et al. 6727 (CMPR!); ibid., 20 April 2010, P.S. Udayan et al. 6729 (CMPR!); Pathadipalam, \pm 740 m, 29 January 2015, P.K. Fasila 137406, 137407 (CALI!); Swapnamudi, \pm 700 m, 26 December 2014, P.K. Fasila 137402 (CALI!). Palakkad Dist.: Siruvani, \pm 900 m, 24 October 1968, D.B. Deb 31071 (MH!); Way to Ommala, \pm 725 m, 02 November 1976, E. Vajravelu 48931 (MH!); Siruvani Dam, \pm 1100 m, 25 February 1982, K.S. Prasannakumar 10283 (CALI!); Sispara, 08 March 2009, P.S. Udayan \& A.J. Robi 5713 (CMPR!). Malappuram Dist.: Nadukani, 02 October 1981, Philip Mathew 28794 (CALI!); New Amarambalam, \pm 1800 m, 16 December 1999, R. Jayakumar 21330 (KFRI!); New Amarambalam, Erumala, \pm 1500 m, 12 February 2000 , R.Jayakumar 21392 (KFRI!). Kozhikode Dist. ibid.,25 March 2008, P.S. Udayan et al. 4890(CMPR!); Ambalappara, 20 January 2009, P.S. Udayan et al. 5445 (CMPR!). Wayanad Dist.: Kerala, \pm 2200 m, 19 July 1970 , E. Vajravelu 34914 (MH!); Wayanad, \pm 740 m, 11 December 1997, K. Shyjan 60131 (CALI!); Pookode, \pm 720 m, 11 December 1997, P.S. Sijimol 59633 (CALI!); ibid., \pm 720 m, 11 December 1997, Lincy Antony 59736 (CALI!); Thariyode. $\pm 700 \mathrm{~m}, 16$ January 1998, R.T. Blalakrishnan, 40698 (CALI!); Soochipara, \pm 780 m, 11 December 1998 , 
K.B. Bindhu 62049 (CALI!); ibid., \pm 800 m, 11 December 1998, K. Sinitha 59441 (CALI!); ibid., \pm 740 m, 10 April 2001, A.K. Pradeep 80553 (CALI!).

\section{Distribution of the two species of Litsea}
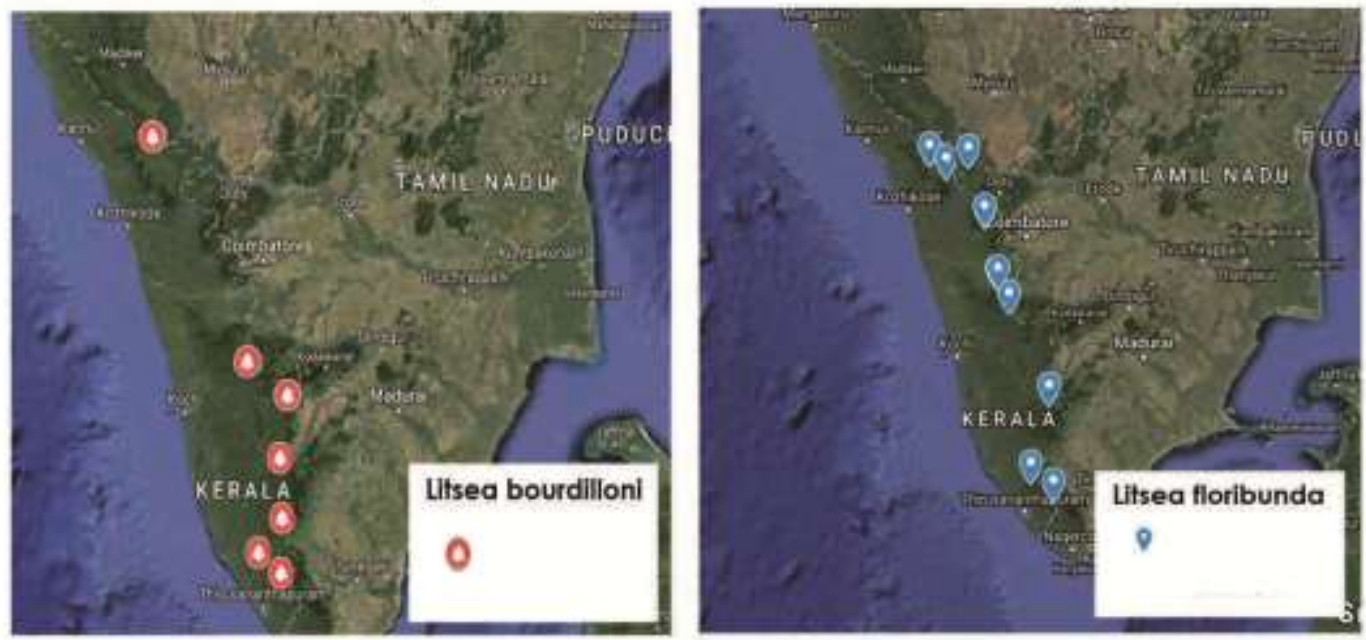

\section{Community Composition and Niche}

Importance Value Index of the two species and other species within the associated vegetation in the study area showed that both species sympatrically occur in the lower tree strata of the medium elevation wet evergreen forests dominated by Palaquium-Cullinia-Mesua type at an altitude range $700-1200 \mathrm{~m}$ MSL.

The dominant trees associated with them are Palaquium ellipticum, Cullinia excilirata, Mesua ferrea and Vateriaindica as the very large trees, Myristica beddomei, Elaeocarpus tuberculatus, Dysoxylum malabaricum, Drypetus malabarica. Litsea oleoides as the large trees, Reinwardtiodendron anaamalaiense, Otnephelium stipulatium, Drypetes venusta, Macaranga peltata, Alseodaphne semicarpifolia, Meliocop elunu-ankenda, Phoebe lanceolata, Litsea coriacea as the medium sized trees, Gymnacranthera farquitiariana, Glochidion zeylanicum, Aglaia barberi, Dimocarpus longan as the small trees and Litsea bourdillonii, Litsea floribunda, Antidesma montanum, Oreocnide integrifolia, Baccaurea courtallensis as the very small trees.

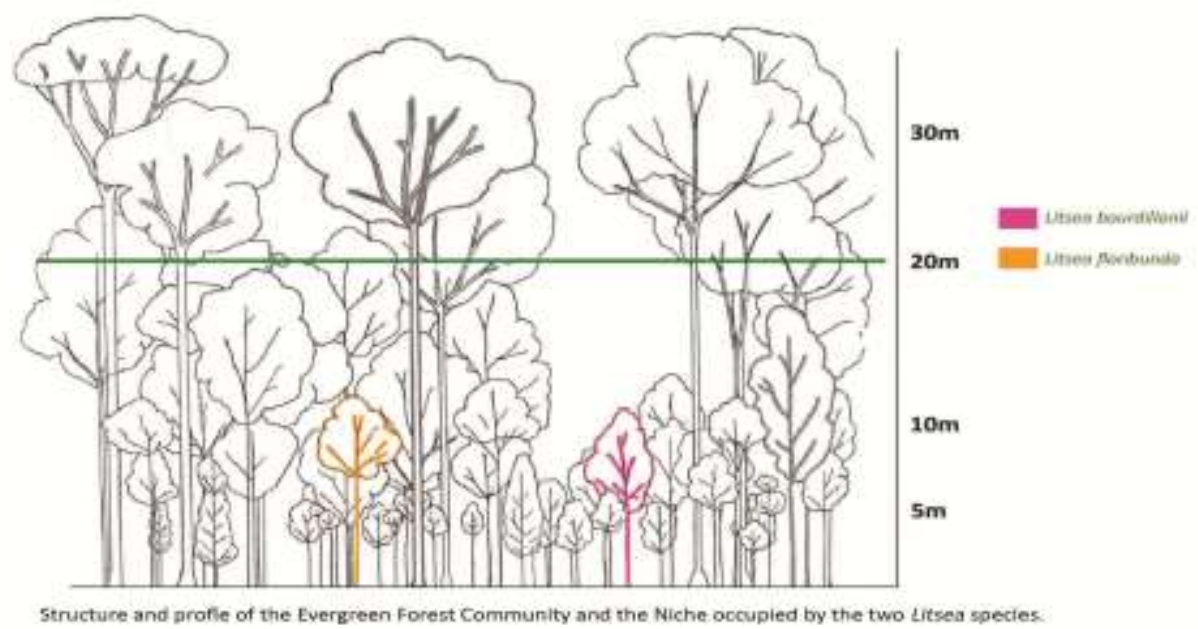




\section{Community Composition and Niche of the two Species of Litsea}

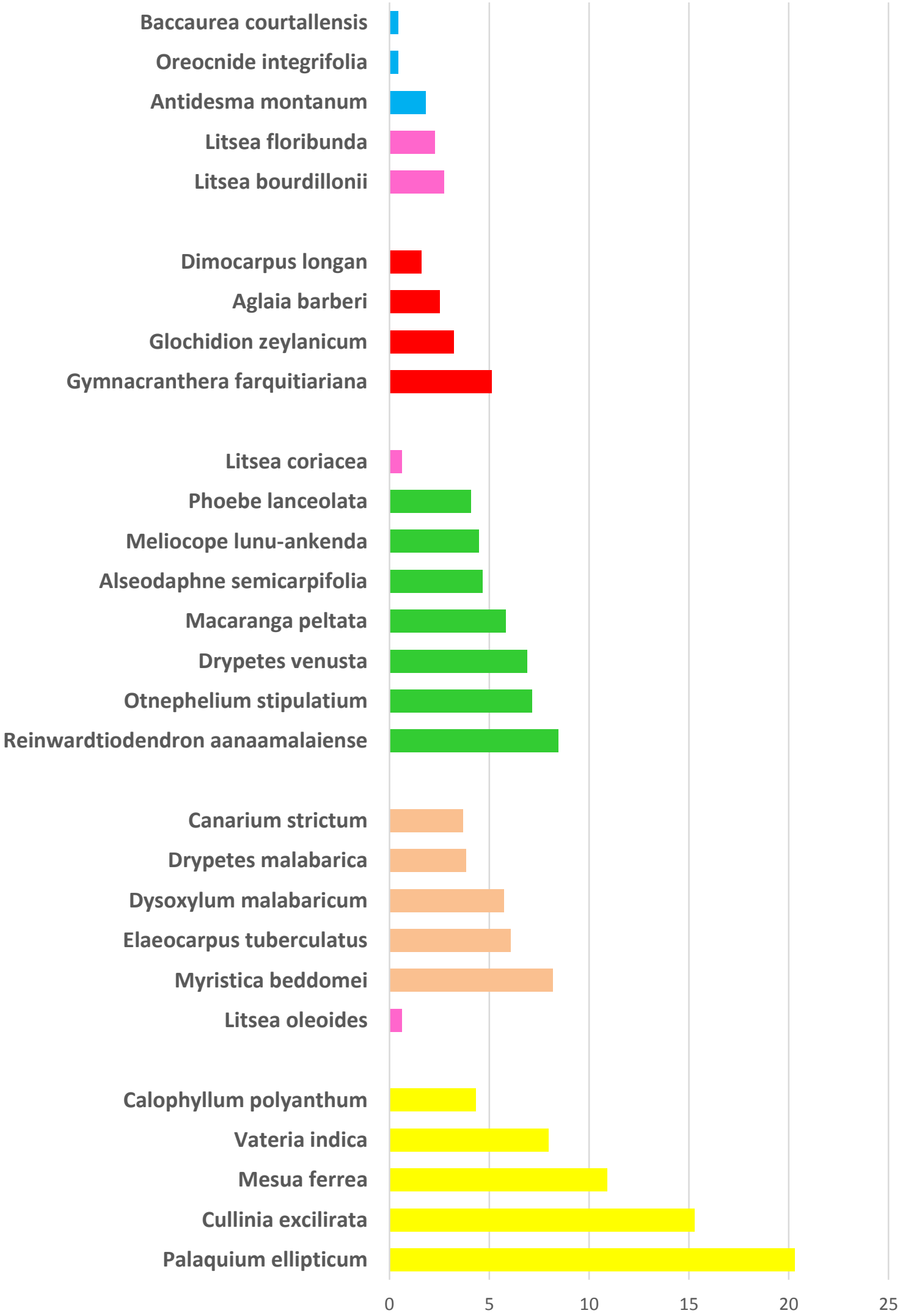



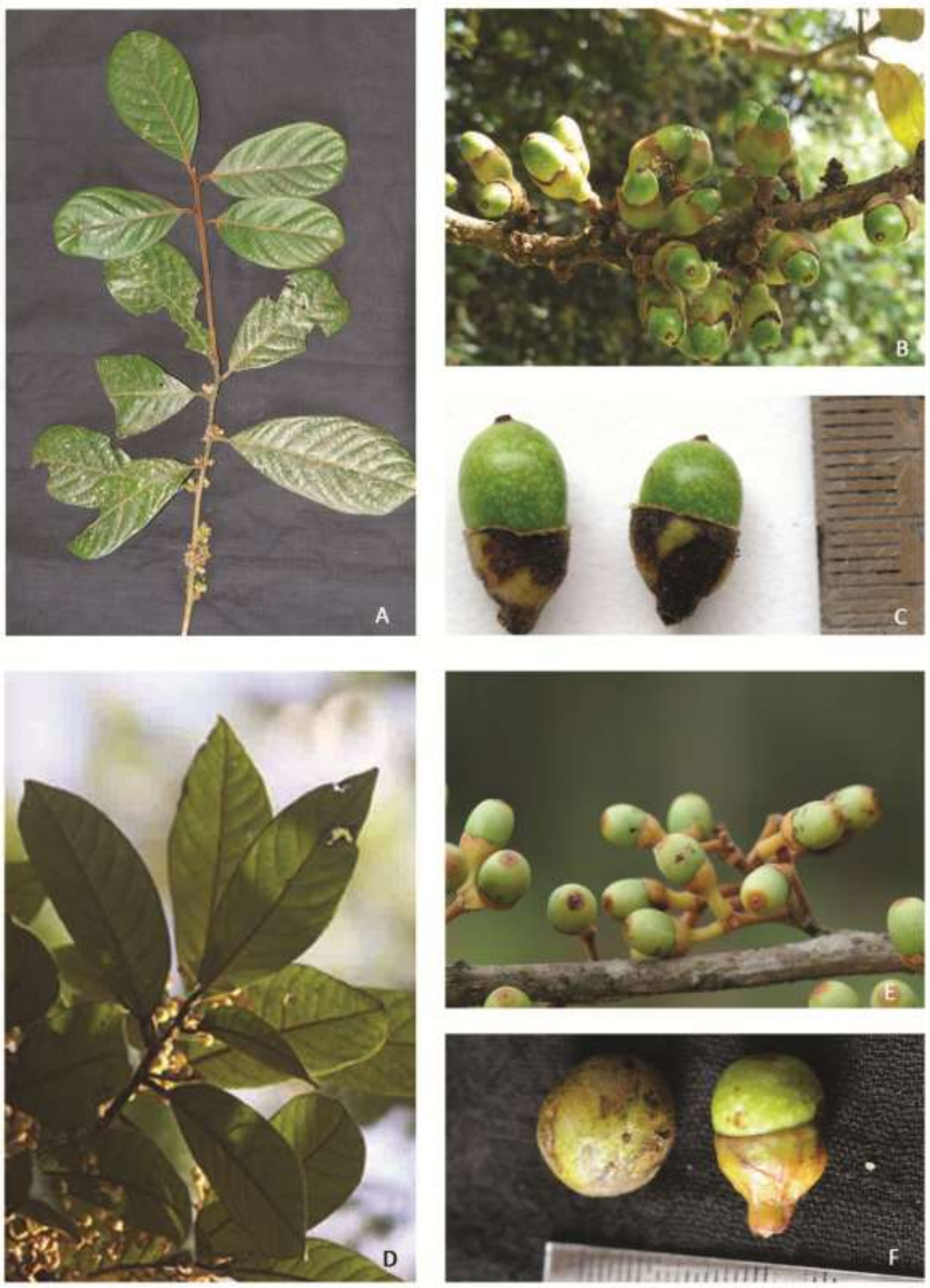

Plate 1. Litsea bourdilloni Gamble. A. \& B. Fruiting twig, C. Fruit; Litsea floribunda (Blume) Gamble. D. \& E. Fruiting twig, F. Fruit 

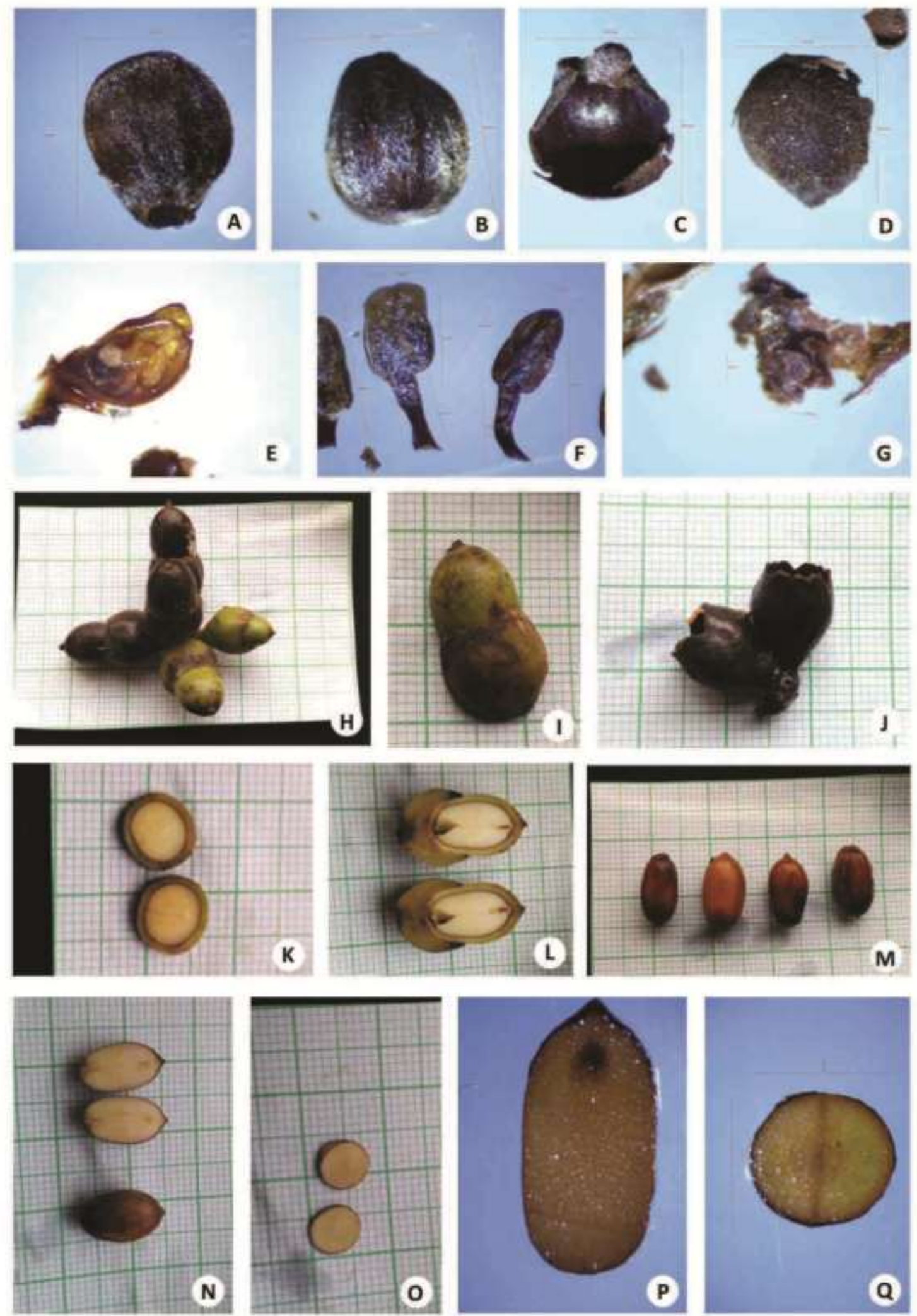

Plate 2. Litsea bourdilloni Gamble. A, B. Flower Buds; C, D, Bract; E. Bud LS.; F. Stamen; G. Gynoecium; H. Cluster of fruits; I. Single fruit; J, fruting perianth tube; K. CS of fruit; L. LS of fruit; M. Mature seed; O. CS of seed; P. LS of mature seed; Q. CS of mature seed. 

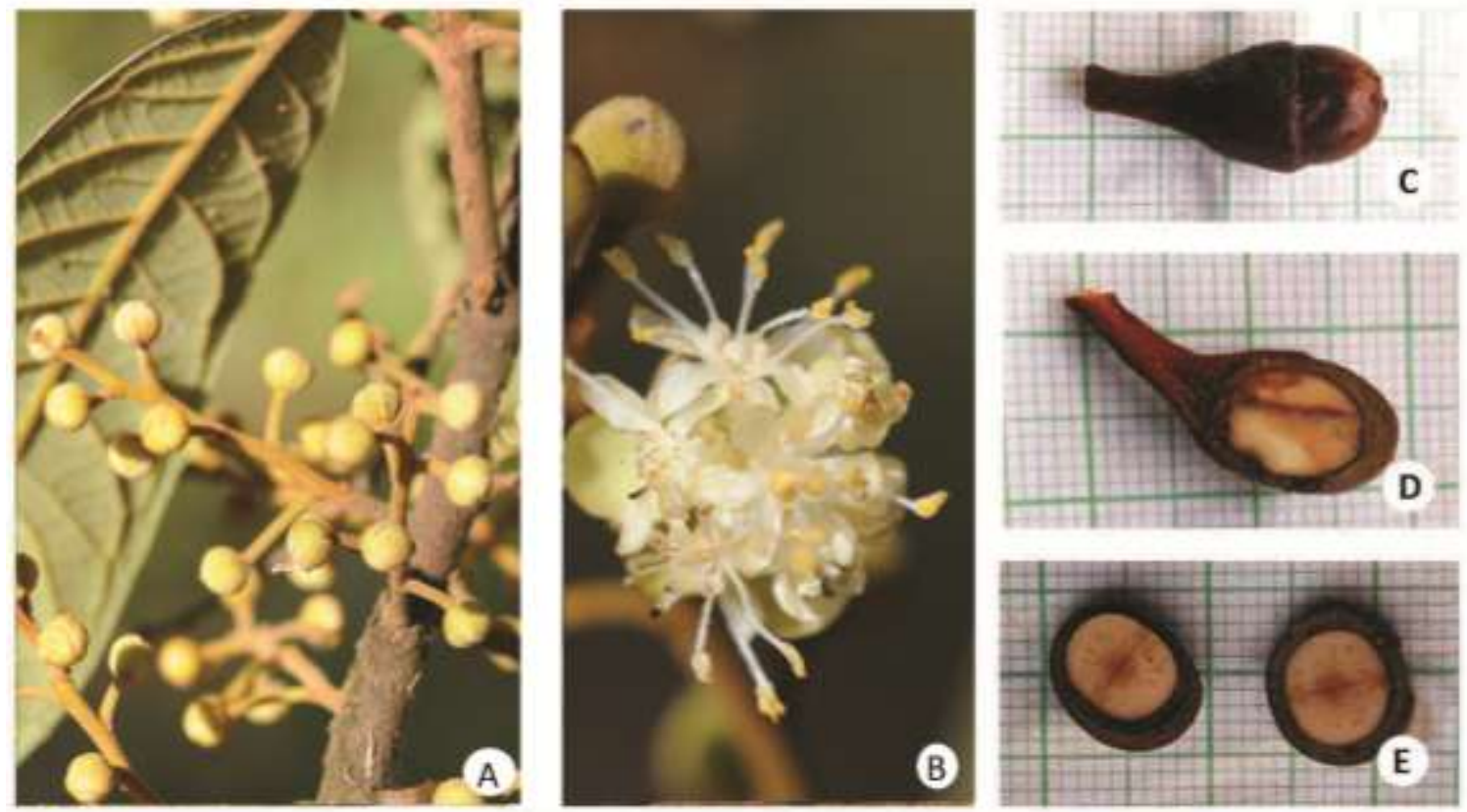

B
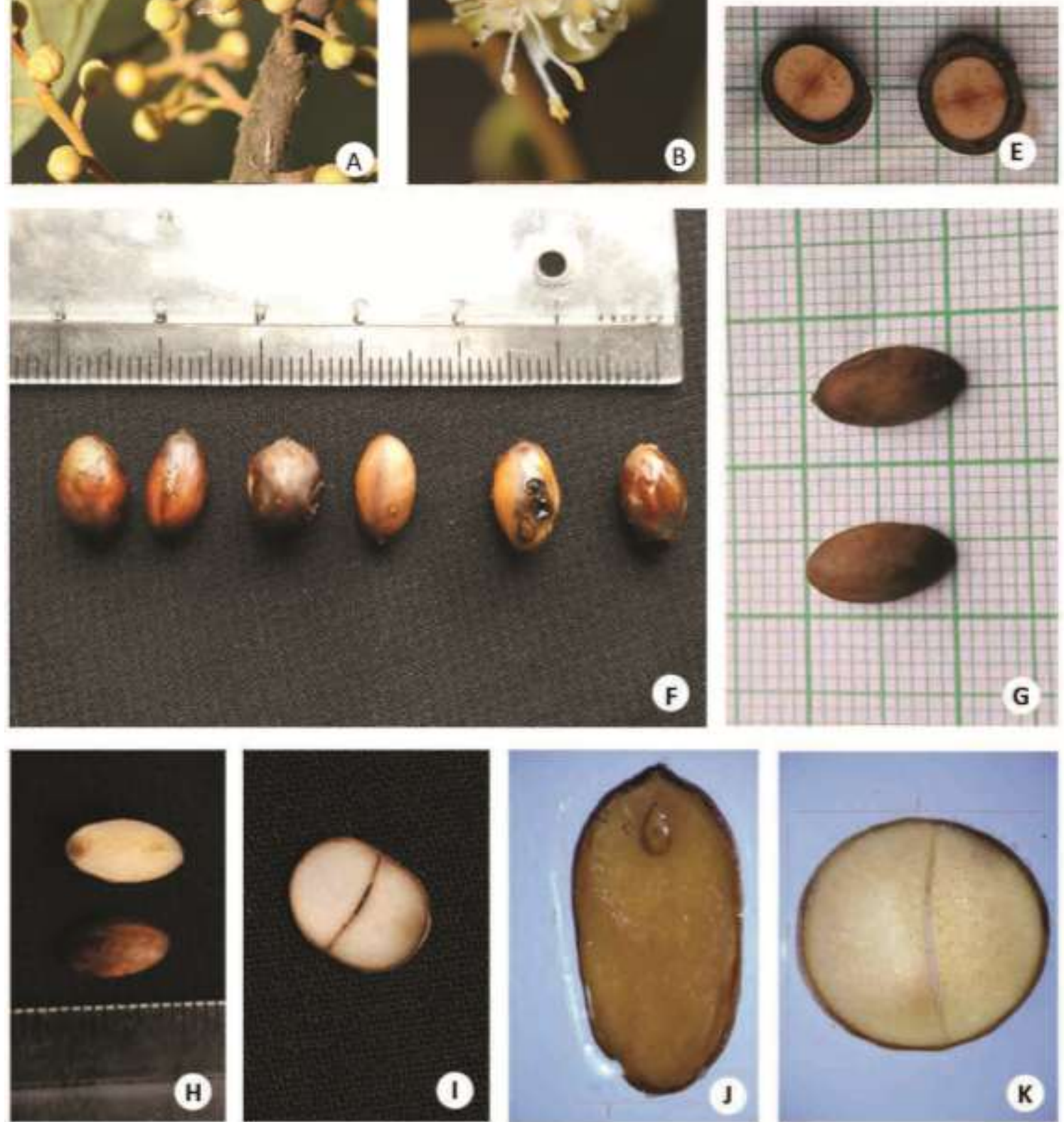

Plate -3. Litsea floribunda (Blume) Gamble. A. Twig with bud, B. Flower, C. Fruit, D. Fruit LS, E. Fruit CS, F \& G. Seeds, H. Seed LS, I. Seed C.S, J. \& H. LS \& CS of Seed showing embriyo 


\section{References:-}

1. Anilkumar, N., Sivadasan, M. \& N. Ravi, (2005). Flora of Pathanamthitta District, Kerala, Daya publishing House. New Delhi.

2. Bhuinya, T., P. Singh, \& S. K. Mukherjee. (2010). An account of species of Litsea Lam. (Lauraceae) endemic to India. Bangladesh J. Pl. Taxon. 17(2):183-191.

3. Brummitt, R. K. \& C. E. Powel, (1992). Authors of Plant Names. Royal Botanic Garden, Kew, England.

4. Christenhusz, M. J. M. \& Byng, J. W. (2016). The number of known plant species in the world and its annual increase. Phytotaxa. Magolia Press. 261(3): 201-217.

5. Gamble, J. S. (1925). Flora of Presidency of Madras. Volume II, Part VII - Nyctaginaceae to Euphorbiaceae. Adlard \& Son Ltd., London

6. Hooker., J. D. (1886). Laurinae, IN: J. D. Hooker (editor). The Flora of British India, Vol. 5. L. Reeve, London

7. IUCN. (2016). IUCN Red List Categories and Criteria Version 12. Prepared by the IUCN Species survival commission, Gland, Switzerland.

8. Mabberley, D. J. (2008). The Plant Book: A Portable Dictionary of plants, their classification and uses. Third Edition. Cambridge University Press., Cambridge, pp.496

9. Mohanan, N. \& M. Sivadasan. (2002). Flora of Agasthyamala. Bishen Singh Mahendra Pal Singh, Dehradun, India. 568.

10. Saldanha, C. J, (1984). Flora of Karnataka vol. 1 Oxford \&IBH publishing Co., New Delhi.

11. Sasidharan N. and V. V. Sivarajan (1996). Flowering plants of Thrissur forest. Scientific publishers, Jopdhpur.

12. Sasidharan N. Aug (2004). Biodiversity documentation for Kerala, part 6: Flowering plants., KFRI handbook no. 17, 398-399.

13. Singh, R. K. (2015). Typification of seven species of Litsea (Lauraceae) endemic to India. Phytotaxa 201(4): 278-286.

14. Van Balgooy, M. M. J. (1987). A plant geographical analysis of Sulawesi. In: Whitmore, T. C. (ed.) Biogeographical Evolution of the Malay Archipelago, pp. 94-102. Oxford: Clarendon Press.

15. Whitmore T. C., (1973). Frequency and habitat of tree species in the rainforest of UK Kelanten. Garden's bullet Singapore, 26, 195-21.

16. Wight R. (1852). Icones Plantarum Indiae Orientalis, vol. 6. Franck and co., Madras. 